\title{
Tae-Bo Egzersiz Programının Üniversiteli Kadın Öğrencilerde Fiziksel Motorik ve Psikososyal Çıktıları*
}

\section{The Physical Motoric and Psychosocial Outcomes of Tae-Bo Exercise Program in University Female Students}

\author{
Ali Tekin, ${ }^{\text {a,** }}$ Gülcan Tekin, ${ }^{\mathrm{b}}$ Emrah Aykora, ${ }^{\mathrm{c}}$ Melih Çalışır ${ }^{\mathrm{d}}$ \\ ${ }^{a}$ Doç. Dr., Bitlis Eren Üniversitesi, Beden Eğitimi ve Spor Yüksekokulu, Antrenörlük Eğitimi Bölümü, 13000, Bitlis/Türkiye. \\ ORCID: 0000-0003-4029-5424

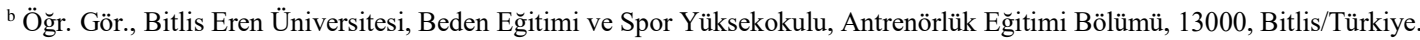 \\ ORCID: 0000-0003-1225-9231

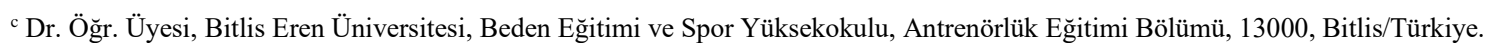 \\ ORCID: 0000-0003-1225-9231 \\ d Öğr. Gör., Bitlis Eren Üniversitesi Sosyal Bilimler Meslek Yüksekokulu, Antrenörlük Eğitimi Bölümü, 13000, Bitlis/Türkiye. \\ ORCID: 0000-0002-2133-2843
}

\section{MAKALE BILGGISI}

\section{Makale Geçmişi:}

Başvuru tarihi: 22 Aralık 2017

Düzeltme tarihi: 10 Şubat 2018

Kabul tarihi: 11 Şubat 2018

\section{Anahtar Kelimeler:}

Aerobik Egzersiz

Sağlık

Obezite

Fiziksel Uygunluk

\section{ARTICLE INFO}

\section{Article history:}

Received 22 December 2017

Received in revised form 10 February 2018

Accepted 11 February 2018

\section{Keywords:}

Aerobic Exercise

Health

Obesity

Physical Fitness
ÖZ

Bu çalışmada, tae-bo egzersiz programına katılımın sedanter ve aşırı kilolu üniversiteli kadın ögrencilerinin fiziksel, motorik ve psiko-sosyal parametrelerine etkisini belirlemek amaçlanmıștır. 74 kadın öğrenci çalışmaya alınmış, bu öğrencilerden tesadüfi yöntemle Egzersiz Grubu (EG: 37) ve Kontrol Grubu (KG: 37) oluşturulmuştur. EG, 16 hafta boyunca egzersizlere katılmıştır. Boy (B), vücut ağırlı̆̆ 1 (VA), vücut yağ yüzdesi (VYY), bel/kalça oranı (BKO), vücut kitle indeksi (VKİ), sağ ve sol el kavrama kuvveti (EKK), sırt kuvveti (SK), bacak kuvveti (BK), esneklik (E), maksimum oksijen tüketimi ( $\mathrm{VO}_{2 m a k s}$ ), sosyal fizik kaygıs1 (SFK), özsayg1 (ÖS), olumsuz ruhsal belirtiler, genel fiziksel yeterlik (GFY) ve kendine güven (KEG) ölçümleri yapılmıştır. Analizlerde eşli ve bağımsız örneklem t-testleri ve Pearson korelasyon katsayısı (rxy) kullanılmıştır. Tae-bo egzersizine katılım; VA, BKO, VKİ, SK, BK, E, VYY, VO 2 max gibi fiziksel ve motorik değişkenler ile SFK, KSE, ÖS, GFY ve KEG gibi psikososyal değişkenlere olumlu etki yapmıştır.

\section{A B S T R AC T}

In this study, it was aimed to expose the influence of participation in tae-bo aerobic exercise program on the physical, motoric and psychosocial parameters of sedentary and overweight university female students. 77 students were included in this study and the EG $(n=37)$ and CG $(n=40)$ were formed by those students randomly. EG participated in 48 exercises during 16 weeks. Height $(\mathrm{H})$, body weight (BW), body mass index (BMI), body fat percent (BFP), waist-hip ratio (WHR), right and left handgrip (HG), leg strength (LS) and back strength (BS), flexibility (F), $\mathrm{VO}_{2 \max }$, social physique anxiety (SPA), self-esteem (SE), negative psychological symptoms (NPS), general physical competence (GPC) and self-confidence (SC) measurements were taken. Independent and paired t-tests and Pearson product-moment correlation coefficient were utilized for analysis. Tae-bo exercise had a positive effect on physical and motoric and psychological variables such as BW, WHR, BMI, BS, LS, F, BFP, and $\mathrm{VO}_{2 \max }$ and also on psychosocial variables such as SPA, SSI, SE, GPC and SC.

\section{Giriş}

Obezite, vücuda besinler ile alınan enerjinin, harcanan enerjiden fazla olmasından kaynaklanır ve vücut yăg kitlesinin, yağsız vücut kitlesine oranının aşırı artması sonucu boy uzunluğuna göre vücut ağırlığının arzu edilen düzeyin üstüne çıkmasıdır.

\footnotetext{
* Bu çalışma, Bitlis Eren Üniversitesi (BEÜ) Bilimsel Araştırma Proje Birimi (BEBAP 2014.13) tarafından desteklenmiş ve 23-26 Kasım tarihlerinde Manisa'da düzenlenen Dünya Spor Bilimleri Araştırmaları Kongresi’nde bildiri olarak sunulmuştur.

** Sorumlu yazar/Corresponding author.

e-posta: atekin@beu.edu.tr
} 
Vücut yağ dokularının düzenlenmesi ve obezite genetik yapı, çevresel uyarıcılar ve gelişimden etkilenir. Beslenme ve fiziksel aktivite davranışındaki değişmeler obezite ile yakın ilişkilidir. İnsülin direnci, hipertansiyon, koroner kalp hastalı̆̆ı, inme, safra kesesi hastalıkları, uyku apnesi, solunum yolu problemleri ve birçok kanser çeşidi şişmanlık ile ilişkilendirilmektedir (Pi-sunyer, 2009). Obezitenin ayrica duygudurum, anksiyete, somatoform (Britz vd., 2000) ve depresyon ile ilișkisi bilinmekte (Siegel vd., 2000), anksiyete bozuklukları arasında da sosyal fobinin daha sık görüldüğü (Eren ve Erdi, 2003) bildirilmektedir. Obezitede beden imajı bozukluğu ve stigmatizasyona yatkınlık olduğu, obez bireylerde sosyal kaçınmanın ortaya çıktığı belirtilmektedir. Sosyal ortamlardan kaçınma davranışı obez bireylerde depresyon ve diğer bozuklukların gelişmesine katk1da bulunabilir (Eren ve Erdi, 2003). Obezler, beden imajlarını kötü algılayıp, vücutlarını beğenmeyebilir veya acayip bulabilirler. Genelde başkalarının da kendilerini bu yüzden çirkin bulduğunu, gülünç karşıladığını, hor gördüğünü, düşmanlık beslediğini düşünebilirler (Aydın ve Yiğit, 2003).

Obezite ve aşırı kilo uzun yıllardır üzerinde çalışılan konulardır. Özellikle son yıllarda obezite prevalansındaki artış ile konu üzerindeki çalışmalar ivme kazanmıştır. Aşırı şişmanlık ve obezitenin önlenmesi için düzenli fiziksel egzersiz son derece önemlidir. Egzersiz; planlı yapılandırılmış, istemli, fiziksel uygunluğun bir ya da bir kaç unsurunu geliştirmeyi amaçlayan sürekli aktivitelerdir. Egzersizin amacı oksijen dağılımını ve metabolik süreçleri yoluna koymak, kuvveti, dayanıklılığı geliştirmek, vücut yağını azaltmak, kas-eklem hareketlerini iyileştirmektir. Sağlık risklerine göre en etkili ve kolay sürdürülebilen egzersizler aerobik olanlardır. Aerobik egzersiz, daha uzun süreli fakat daha az kuvvet harcanarak yapılır. Aerobik egzersizde sadece kastaki depolanmış enerji kaynakları (yă dokusundaki yağ ve karaciğer glikojeni) kullanılmaktadır. Aerobik egzersiz dayanıklılığı inşa eder ve kalbin pompalama yeteneğini dengede tutar, uzayan dönemlerde çalışma oranını yükseltir. Düzenli uygulamalar kardiyak fonksiyonları güçlendirir ve omurgayı kuvvetlendirir. Ayrıca vücut yağ oranını azaltarak dış görünümü düzenler, kendini iyi hissetme duygusunu oluşturur, stres ile mücadelede en iyi çaredir ve psiko-sosyal sorunların azaltılması veya engellenmesinde aerobik egzersizlerle yüksek verim elde edilebilir.

Aerobik egzersizlerin, kilo kaybı sağlarken yağsız vücut kitlesini arttırdığı (Moinuddin vd., 2012), bel çevresi ölçümünü (Thorogood, 2011) ve bel-kalça oranı (Vatansev ve Çakmakçı, 2010), vücut yağ yüzdesi (Akdur, 2011) ve vücut kompozisyonunu (Bredin, vd., 2013) olumlu etkilediği; kassal dayanıklılık, kassal kuvvet (Kurt vd., 2010) ve aerobik uygunluğu arttırdığı (Bredin vd., 2013) dolayısıyla genel fiziksel yeterlilik ve görünüme katkı sağladığı (Köksal vd., 2006) netice olarak fiziksel ve genel sağlığ 1 iyileştirdiği (Buffart vd., 2014) bildirilmiştir.

Aerobik egzersiz; yorgunluk algısı, depresyon, sosyal aktiflik ve yaşam kalitesini etkiler (Roppolo vd., 2013; Gordon vd., 2013). Aerobik egzersiz aynı zamanda stres (Vancampfort vd., 2011; Yeltepe ve Yargıç, 2011), depresif semptomlar (Gerber vd., 2013; Gary, 2013) ve kaygının (Asmundson vd., 2013) azaltılmasında etkilidir. Bu etki özellikle orta düzey aerobik egzersiz sonucu daha çok görülmektedir (Ho vd., 2014). Bunlara ilaveten, fiziksel egzersizin algılanan fiziksel yeterliği arttırarak sosyal fizik kaygının azalmasına (Sabiston vd., 2014; Sicilia, 2014), beden imgesi ve duygusal denge (Cooper, 2013) ve özsaygının (Salamuddin vd., 2014) artmasına destek olduğu raporlanmıştır.

İçinde müzik ve ritim olan, tempolu, eğlenceli ve çeşitli fiziksel aktiviteler egzersizin zevkli ve uzun süreli yapılabilmesini sağlamaktadır. Yoğun ilgi gösterilen aerobik egzersizlerinin farklı formatlarının ortaya çıkarılması, bu egzersiz çeşidine olan katılımı da oldukça artırmaktadır. Aerobik; müzik eşliğinde, özellikle kilo vermek amacıyla uygulanan, kas aktivitesi açısından kas gruplarını yoğun bir şekilde çalıştıran, eğlenceli bir egzersiz yöntemidir (Tortop vd., 2010).

$\mathrm{Bu}$ araştırmada aerobik egzersiz olarak uygulanacak olan Tae-Bo, 2000'li yıllarda popüler olmaya başlayan aerobik egzersiz türüdür. Tekvando pratisyeni Billy Blanks tarafından geliştirilmiştir. Tae-bo kelimesi, Korece'de ayak ve bacak anlamına gelen "tae" ve İngilizce' deki boks anlamına gelen "boxing” kelimelerinin kısaltmasıdır. Tae-bo egzersizi tekvando, karate, boks, bale ve hip-hop hareketlerinin birleşiminden oluşur ve müzik eşliğinde uygulanır. Bu egzersiz esnasında kalp atım sayısı "yağ yakım eşiği" düzeyine gelir ve o seviyede belirli bir süre kalır. Taebo, kardio-vasküler ve kas sistemini geliştirmesinin yanında koordinasyon, denge ve esnekliği olumlu etkileyen kapalı alan (stüdyo) çalışmaları içerisinde, en etkili aerobik egzersiz türlerindendir. Bir saatlik bir çalışma sonucunda 500-800 kalori harcanır ki bu 300-400 kalorinin yakılabildiği geleneksel aerobik çalışmalarına göre daha fazladır (Hižnayová, 2013; Greer, 2016).

Bu kapsam doğrultusunda, gönüllü sedanter kadın üniversite öğrencilerinden aşırı kilolu olduğu bilimsel tekniklere göre belirlenenlerden oluşturulacak olan katılımcı grubuyla, 16 hafta boyunca yürütülecek olan bu araştırmanın amacı, öğrencilerin fiziksel, motorik ve psiko-sosyal özelliklerindeki değişimin belirlenmesidir.

\section{Yöntem}

Araştırmanın verilerini toplamak amacıyla niceliksel deneysel araştırma modellerinden kontrol gruplu ön ve sontest modeli kullanılmıştır.

\subsection{Bağlam ve Katılımcılar}

Çalışma Bitlis Eren Üniversitesi Yerleşkesi'nde yer alan farklı bölümlerde öğrenim gören gönüllü kadın öğrencileri kapsamıştır. Öğrencilerin fiziksel aktiflikleri Fiziksel Aktivite Değerlendirme (FAD) Anketi (Karaca vd., 2000) ile belirlenmiştir. FAD anketinde rapor edilen tüm aktivitelerin kilokalori/hafta değerleri toplanmış (Lee vd., 1992), kilokalori/hafta değeri aktivitelerin MET/hafta değerleri ve bireylerin vücut ağırlıkları çarpılarak bulunmuş (Ainsworth vd., 1993), aktivitelerin MET/hafta değerleri ise Karaca vd. (2000) kullandığ1 yöntemle hesaplanmıştır. FAD anketine göre hesaplanan haftalı enerji tüketimi 1000 kilokalori/hafta'dan az olanlar sedanter (Lee vd., 1992) olarak kabul edilmiştir. Tüm katılımcılardan egzersiz yapmasına engel teşkil edebilecek fiziksel, fizyolojik ve metabolik hastalıklarının olmadığına dair sağlık raporu 
istenmiştir. Kardiyopulmoner ve iltihaplı eklem diz dahil sistemik patoloji; bir ağrı ile ilgili yaralanma ve cerrahi öyküsü, aktif müdahalesi ya da son 2 ay içinde bir antiinflamatuar ilaç, kortikosteroid, veya hydrodilatation enjeksiyon veya fizik tedavi de dahil olmak üzere son 3 ay içerisinde kriterlerden herhangi biri mevcut olanlar çalışmaya dahil edilmemiştir. Herhangi bir sağlık sorunu olmayan, en az 2 yıldır sedanter yaşam tarzı sürdükleri ve aşırı kilolu/obez oldukları yukarıda açıklanan yöntemlerle belirlenen 77 öğrenciye çalışma ile gerekli tüm bilgiler araştırmacılar tarafından verilmiş, gönüllü katılım prensibi anlatılmıştır. Egzersiz programında yer alan öğrencilerden en fazla 3 oturuma katılmayanların çalışma dışında bırakılacağı hatırlatılmıştır. Daha sonra katılımcılar EG'ye 37, KG'ye 40 olmak üzere tesadüfi olarak dağıtılmıştır. Kontrol grubundan normal yaşantılarına devam etmeleri istenmiş, tüm katılımcılara günlük beslenmelerine her zamanki gibi devam etmeleri söylenmiş, egzersiz grubunda yer alanların egzersiz esnasında ve sonrasında su içebilecekleri belirtilmiştir. Veri toplama araçlarında eksik işaretleme yapan KG grubundan 3 katılımcıya ait bulgular değerlendirmeye alınmamıştır.

Egzersiz programı, Bitlis Eren Üniversitesi Yerleşkesinde bulunan mücadele sporları salonunda yürütülmüştür. Fiziksel ve motorik ölçümler aynı spor salonunda proje kapsamında temin edilen teçhizatla oluşturulan BESYO Spor Fizyolojisi Laboratuvarı'nda alınmıştır. Envanter, anket ve ölçek uygulamaları BESYO toplantı odasında tek oturumda ön ve son test olarak yapılmıştır. EG 16 hafta boyunca haftada 3 gün 60 dakika süren, kalp atım sayısının 50-60 şiddetinde taebo aerobik egzersiz programına katılmıştır. Her egzersiz oturumu 15 dakika ısınma (warmup) yürüyüşü/çok hafif tempolu koşu ile başlamış sonrasında 15 dakika esnetme çalışması yapılmıştır. Devamında, karatedo, taekwon-do, kick-boks ve muay-thai (Tayland boksu) gibi sporlarda kullanılan tekme ve yumruk serileri, yüksek ritimli müzik eşliğinde 30 dakika uygulanmıştır. Katılımcılar tüm hareketleri eğitmen eşliğinde eşzamanlı (senkronize) olarak yapmaya çalışmışlardır. Bu çalışmalarda dövüş teknikleri karşılıklı olarak uygulatılmamış ancak temel teknikler doğru bir şekilde öğretilmeye gayret edilmiştir. Oturumun son 15 dakikası soğuma egzersizlerine (cool-down) ayrılmıştır. Egzersizin şiddeti, egzersiz bitiminden hemen sonra boyundaki karotid atardamardan 10 saniyedeki kalp atım sayımı sonucunda Karvonen metoduna göre hedef kalp atım sayısı (HR) yöntemi ile tespit edilmiştir (Zorba, 1995).

[Formül: $\quad H_{\max }=220$-Yaş, $\quad H R=H R_{\max }-H R$ dinlenik, \%60 $\mathrm{THR}=(0.60 \mathrm{x}$ HRR $\left.)+\mathrm{HR}_{\text {dinlenik }}\right]$

\subsection{Verilerin Toplanmas}

Bilgi Formu: Çalışmada veri toplamak için öncelikle araştırmacılar tarafından hazırlanan sağlık, sosyodemografik özellikler ve obezite ile ilgili sorulardan oluşan Bilgi Formu her iki gruba uygulanmıştır.

\subsubsection{Fiziksel ve Motorik Ölçümler}

B: B ölçümü, denekler ayakta dik pozisyonda dururken Holtain marka kayan kaliper ile skalanın üzerinde kayan kaliper başlarının üzerine dokunacak şekilde ayarlanacak ve uzunluk $1 \mathrm{~mm}$ hassasiyetle okunmuş ve kaydedilmiştir.
VA: VA ölçümü, katılımcıların ayakları çıplakken ve sadece şort ve tişört giymiş halde 20 grama kadar hassas bir kantarda (Angel marka) yapılmıştır (Saygın vd., 2005).

VYY, VKİ ve BKO: Bodystat 1500 Vücut Kompozisyon Analizörü ile ölçülmüştür (Bodystat 1500, Bodystat Ltd, Douglas, British Isles). Bodystat, bio-elektrik empedans analiziyle (BIA) vücut kompozisyonunu ve ilgili parametreleri en hassas şekilde ölçen bir araçtır. BIA salık verilen protokole göre yapılmıştır (Kyle vd., 2004).

Dünya Sağlık Örgütü (DSÖ), VKI'si 25-29,9 arasında olan bireyleri kilolu, 30 veya üzerindekileri obez olarak tanımlamaktadır. Dolayısıyla aşırı kiloluluk VKİ değeri 2729,9 arası kabul edilebilir (Baltacı, 2008). DSÖ obeziteyi sadece VKİ ile değil aynı zamanda BKO ile de değerlendirmektedir. DSÖ'ye göre BKO kadınlarda $0.85^{\prime}$ den ve erkeklerde ise 1.0 'den fazla ise bu durum android tip obezite olarak kabul edilmektedir.

E: Esneklik ölçümünde standart otur-eriş (sit and reach) sehpas1 (Lafayette Instrument Company, Lafayette, IN) kullanıldı. Sehpa dayanıklı ve hafif alüminyumdan imal edilmiştir. Sehpa üzerindeki skala $1 / 2$ " inç artışlarla, 23 "e ve santimetre olarak $59 \mathrm{~cm}$. dir. Katılımcilar 5 dakika ısınmadan sonra ayakları düz ve panele dayanmış bir şekilde oturdular, dizlerini bükmeden gövdelerini ileri doğru eğdiler, elleriyle kayan barı maksimum seviyede itmeye çalıştılar. En uzak noktada öne ya da geriye esnemeden 1-2 sn. beklendi. İki denemede daha iyi olan değer kaydedildi.

EKK: Takei marka TKK 5401 model (Grip- D, Takei Scientific Instruments Co. Ltd., Tokyo, Japan) el dinamometresi ile ölçüm yapıldı. Araç, sol ve sağ ön kol bükücü kasların gücünü 3 haneli LCD (dijital) ekranda kgf cinsinden görüntüler. Ölçüm aralığı 5.0-100 kgf, minimum ölçüm artışı $0.1 \mathrm{kgf}$ ve hassasiyeti $\pm 2.0 \mathrm{kgf}$ dir. Beş dakika 1sınmadan sonra dinamometre katılımcının eline göre ayarlandı. Katılımcı ayakta iken ölçüm yapılan kolu bükmeden ve vücuda temas etmeden kol vücuda $30^{\circ}$ 'lik açı yaparken ölçüm alındı. Bu durum sağ ve sol el için iki defa tekrar edildi ve en iyi değer kaydedildi. Tekrarlar arasında 30 sn. dinlenildi (Halder vd., 2015).

BK ve SK: Ölçüm, Takei marka TKK 5402 model (Back-D, Takei Scientific Instruments Co. Ltd., Tokyo, Japan) sirtbacak dinamometresi yapıldı. Araç, sırt ve bacak kuvvetini 3 haneli LCD (dijital) ekranda kgf cinsinden görüntüler. Ölçüm aralığ 1 20-300 kgf, minimum ölçüm artış1 0.5 kgf ve hassasiyeti $\pm 0.6 \mathrm{kgf}$ dir. Beş dakika 1sınmadan sonra, bacak kuvveti ölçümü için katılımcı ayakta dizleri bükük durumda iken ayaklarını dinamometre sehpasının üzerine yerleştirdi. Kollar gergin, sırt düz, gövde hafifçe öne eğik, dizler bükülüyken elleri ile kavradığı dinamometre barını bacaklarını kullanarak dikey olarak maksimum oranda yukarı çekti (squat pozisyonunda yükselme). Bu çekiş iki defa tekrar edilip en iyi değer kaydedildi. Tekrarlar arasında 30 sn. dinlenildi (Halder vd., 2015). Sırt kuvveti aynı dinamometre ile ölçüldü. Katılımcı beş dakika ısınmadan sonra ayaklarını dinamometre sehpasının üzerine yerleştirdi. Kollar gergin, sırt ve dizler düz gövde hafifçe öne eğikken elleri ile kavradığı dinamometre barını dikey olarak maksimum oranda yukarı çekti. Bu çekiş iki defa tekrar edilip en iyi değer kaydedildi. Tekrarlar arasında 30 sn. dinlenildi (Halder vd., 2015). 
$\mathrm{VO}_{2 \max }$ : Monark 928E Model (yeni tip, Varberg, Sweden) Ergonomik Bisiklet-VO ${ }_{2 \max }$ Ölçüm Ergometresi kullanıldı. Modelin patentli direnç sistemi testten önce, test esnasında ve test sonrası direnç kontrolü sağlar. Bisiklet hızdan bağımsız olarak çalışır. Ölçüm esnasında, ekrandan iş gücünü hızdan bağımsız olarak ayarlayabilir. Sınırsız sayıda protokoller oluşturabilir ve PC yazılımında veri analizi, USB portu ile PC bağlantısı yapılabilir. Åstrand, YMCA, WHO veya PWC protokolleriyle $\mathrm{VO}_{2 \max }$ hesaplamasina olanak sağlar. Ölçümler yazılımda Åstrand protokolü işaretlenerek yapıldı. Ana yüklenmeye geçilmeden önce 5 dakika ısınma fazında çalışıldı (Larsen et al., 2014).

\subsubsection{Psiko-sosyal Ölçümler}

\subsubsection{Sosyal Fizik Kaygl Envanteri (SFKE)}

Bireylerin fiziksel görünüşlerinin başkaları tarafından değerlendirilirken hissettikleri kaygıyı ölçmek için Hart vd. (1989) tarafından geliştirilen bu envanter 12 maddeden oluşmaktadır Maddeler 5'li likert tipi değerlendirme ile cevaplandırılmaktadır. Envanterden alınabilecek en düşük puan 12 ve en yüksek puan 60'dır. SFKE'den alınan puan arttıkça kişinin dış görünüşünden duyduğu kaygı düzeyi de artmaktadır. Envanterde 5 madde "kişinin fiziksel görünümü hakkındaki rahatsızlık hissinden" oluşurken, kalan 7 madde ise "kişinin fiziksel görünümünün başkaları tarafından olumsuz değerlendirilme beklentisini" içermektedir. Bu envanterin geçerlilik ve güvenirlik çalışması Mülazımoğlu ve Aşçı (2006) tarafindan yapılmıştır.

\subsubsection{Marsh Kendini Fiziksel Tanımlama Envanteri} (MKFTE)

Kendini Fiziksel Tanımlama Envanteri (Physical SelfDescription Questionnaire, PSDQ) Marsh (1994) tarafından geliştirilmiş ve Türkçe uyarlaması Aşçı (2000) tarafından gerçekleştirilmiştir. Ölçek, dokuz fiziksel benlik kavramı (sağlık, koordinasyon, fiziksel aktivite, vücut yağ, spor yeteneği, görünüm, kuvvet, esneklik, dayanıklılık) ve iki genel benlik kavramı bileşeni (genel fiziksel yeterlik ve kendine güven) olmak üzere toplam 11 alt boyutu içermektedir. Bu çalışmada, ölçüm aracına ait koordinasyon, görünüm, kuvvet, esneklik, dayanıklılık, genel fiziksel yeterlik ve kendine güven boyutları kullanılmıştır. "Sağlık" ve "Kendine güven" boyutları sekiz, diğer boyutlar 6 maddeye sahiptir. Toplam 70 maddeyi içeren ölçek, "1: Tamamen yanlış" ve "6: Tamamen doğru” arasında değişen altılı değerlendirme basamağına sahiptir. Türkçeye uyarlanan PSDQ alt ölçeklerinin iç tutarlık katsayısı Cronbah Alpha 0.87 ve 0.98 arasında değişmektedir (Aşçı, 2000). Bu araştırmada genel benlik kavramı bileşenleri olan genel fiziksel yeterlik (GFY) ve kendine güven (KEG) alt ölçekleri kullanılmıştır.

\subsubsection{Benlik Saygısı Ölçeği (BSÖ)}

Araştırmada benlik saygısı ölçümü için kullanılan ve orijinal formu İngilizce "Rosenberg Self Esteem Scale" ismini taşıyan ölçek, 1963 yılında Morris Rosenberg tarafından geliştirilmiştir. Ölçek Füsun Çuhadaroğlu (1986) tarafından Türkçeye uyarlanmıştır. Bu araştırmada söz konusu ölçeğin kısa formu kullanılmıştır. Ölçek, beş olumlu beş olumsuz ifadenin yer aldığı on sorudan oluşmaktadır. Rosenberg Benlik Saygısı Ölçeği, bireylerin "Çok Doğru”, "Doğru”, "Yanlış", "Çok Yanlış" seçeneklerinden en uygun olanını işaretledikleri dörtlü likert tipi bir ölçektir. Benlik saygısı alt ölçeğinden alınan puanlar, 0-6 arasında olup; 0-1 puan yüksek, 2-4 puan orta ve 5-6 puan düşük benlik saygısını göstermektedir.

\subsubsection{Kisa Semptom Envanteri (KSE)}

Ülkemizde Şahin ve Durak (1994) tarafindan Türkçeye uyarlaması, geçerlik ve güvenirlik çalışması yapılmıştır. Katılımcıların kendi beyanlarına dayalı 53 maddelik 5'li likert tipi bir ölçektir. Maddeler "hiç" ve "çok fazla" ifadelerine karşılık gelen 0-4 değerleri arasında derecelendirilir. KSE; depresyon, anksiyete, olumsuz benlik, somatizasyon ve hostilite alt ölçeklerinden oluşur. Alt ölçek puanlarının hesaplanmasıyla toplam puan elde edilir. Ölçekten alınan toplam puanların yüksekliği, bireyin ruhsal belirtilerinin arttığını gösterir.

\subsection{Verilerin Analizi}

Elde edilen bulgular SPSS İstatistik Paket Programında analiz edilmiş; tanımlayıcı istatistikler verilmiştir. Verilerin normalliği ShapiroWilk testi ile belirlenmiştir. Karşılaştırmalardan önce KG ve EG katılımcılarının ilk ve son ölçüm puanlarının varyans eşitliği gözden geçirilmiş, değerlerin tüm değişkenlerde eşit varyanslara ( $\mathrm{p}>.05)$ sahip olduğu görülmüştür. Yani iki örneklem verisi de normal dağılım gösteren ana kütlelerden gelmektedir. Bu nedenle eşli grupların karşılaştırılmasında parametrik testlerden eşli örneklem t-testi, bağımsız ikili grupların karşılaştırmasında parametrik testlerden bağımsız örneklem t-testi kullanılmıştır. Anlam düzeyi $\mathrm{p}<0.05$ ve güven aralığ $1 \% 95$ 'e göre yorumlanmıştır. Parametrik iki farklı değişken arasındaki ilişkinin yönü ve şiddetini belirleme işlemi parametrik Pearson çarpım-moment korelasyon katsayısı (rxy) ile yapılmıştır.

\section{Bulgular}

Grup içi karşılaştırma sonuçları tae-bo egzersizine katılımın faydalarına işaret etmektedir. EG katılımcılarının ilk ve son ölçüm ortalamalarına göre; tae-bo egzersizine katılımın fiziksel, motorik ve fizyolojik değişkenler olan VA, BKO, VKİ, SK, BK, E, VYY, VO2maks üzerinde olumlu bir etki yarattığı açıktır. Benzer olumlu etki psiko-sosyal değişkenler olarak ele aldığımız SFK, KSE, ÖS, GFY ve KG için de geçerlidir (Tablo 1).

Tablo 1. Katılımcıların Tanımlayıcı İstatistikleri

\begin{tabular}{lcccccc}
\hline & Grup & $n$ & Min. & Maks. & $\overline{\mathrm{X}}$ & ss \\
\hline \multirow{2}{*}{ Yaş } & EG & 37 & 18 & 24 & 20,86 & 1,377 \\
\cline { 2 - 7 } & KG & 37 & 18 & 24 & 20,67 & 1,650 \\
\hline \multirow{2}{*}{ Boy } & EG & 37 & 157 & 175 & 162,11 & 0,041 \\
\cline { 2 - 7 } & KG & 37 & 155 & 170 & 162,62 & 0,036 \\
\hline \multirow{2}{*}{ VA } & EG & 37 & 65,30 & 83,20 & 70,44 & 3,962 \\
\cline { 2 - 7 } & KG & 37 & 65,00 & 80,00 & 69,59 & 3,657 \\
\hline \multirow{2}{*}{ BKO } & EG & 37 &, 90 & 1,04 &, 9765 & 0,033 \\
\cline { 2 - 7 } & KG & 37 &, 89 & 1,04 &, 9735 & 0,026 \\
\hline \multirow{2}{*}{ VKİ } & EG & 37 & 23,90 & 31,31 & 26,8519 & 2,001 \\
\cline { 2 - 7 } EKK & KG & 37 & 23,18 & 31,25 & 26,3678 & 2,008 \\
\cline { 2 - 7 } Sağ & EG & 37 & 11,70 & 32,40 & 21,9243 & 5,164 \\
\hline \multirow{2}{*}{ EKK } & EG & 37 & 12,30 & 33,05 & 22,5730 & 5,131 \\
\cline { 2 - 7 } Sol & KG & 37 & 10,85 & 34,70 & 22,0405 & 5,449 \\
\hline SK & EG & 37 & 30,00 & 97,50 & 64,2973 & 18,18 \\
\hline
\end{tabular}




\begin{tabular}{lllllll}
\hline & KG & 37 & 30,60 & 98,25 & 64,9432 & 18,21 \\
\hline \multirow{2}{*}{ BK } & EG & 37 & 22,50 & 89,50 & 52,2703 & 16,22 \\
\cline { 2 - 7 } & KG & 37 & 23,10 & 89,75 & 52,8905 & 16,25 \\
\hline \multirow{2}{*}{ E } & EG & 37 & 3,17 & 19,56 & 8,9143 & 3,559 \\
\cline { 2 - 7 } & KG & 37 & 2,97 & 19,66 & 8,8684 & 3,56 \\
\hline \multirow{2}{*}{ VYY } & EG & 37 & 16,66 & 36,16 & 25,7041 & 5,06 \\
\cline { 2 - 7 } & KG & 37 & 16,95 & 37,29 & 26,1339 & 5,428 \\
\hline \multirow{2}{*}{ VO2m } & EG & 37 & 23,13 & 50,68 & 38,8211 & 5,998 \\
\cline { 2 - 7 } ax & KG & 37 & 23,13 & 50,48 & 38,7751 & 5,985 \\
\hline \multirow{2}{*}{ SFK } & EG & 37 & 25,00 & 51,00 & 34,7838 & 8,350 \\
\cline { 2 - 7 } & KG & 37 & 26,00 & 50,00 & 35,5676 & 8,398 \\
\hline \multirow{2}{*}{ KSE } & EG & 37 & 25,00 & 175,0 & 101,621 & 36,11 \\
\cline { 2 - 7 } & KG & 37 & 25,00 & 176,0 & 102,405 & 36,18 \\
\hline \multirow{2}{*}{ OS } & EG & 37 & 1,00 & 5,00 & 3,2162 & 1,003 \\
\cline { 2 - 7 } & KG & 37 & 2,00 & 5,00 & 3,2973 &, 845 \\
\hline \multirow{2}{*}{ GFY } & EG & 37 & 10,00 & 28,00 & 20,0270 & 4,913 \\
\cline { 2 - 7 } & KG & 37 & 9,00 & 27,00 & 19,2432 & 4,968 \\
\hline \multirow{2}{*}{ KEG } & EG & 37 & 12,00 & 30,00 & 21,4054 & 4,657 \\
\cline { 2 - 7 } & KG & 37 & 11,00 & 29,00 & 20,6216 & 4,739 \\
\hline
\end{tabular}

Diğer taraftan, egzersiz programı boyunca sedanter yaşamlarına devam eden $\mathrm{KG}$ katılımcılarının bazı değişkenlerinde değişim görülmezken VO2max, SFK, KSE, GFY ve KG puan ortalamalarında başlangıç düzeylerine göre daha kötüye gidiş söz konusudur (Tablo 2).

Gruplar arası karşılaştırmalar grup içi karşılaştırma sonuçlarını büyük ölçüde teyit eder niteliktedir. Gruplar arası karşılaştırmalarda ilk ölçümler açısından herhangi bir etkiden söz edilemezken, son ölçümler; VA, BKO, VKİ, SK, BK, E, VYY, VO2max, SFK, ÖS, GFY ve KG puan ortalamalarında EG katılımcıları lehine olumlu ve anlamlı bir değișim söz konusudur. Gruplar arası karşılaştırmalara göre tae-bo egzersizine katılım KSE ve EKK'yi etkilememiştir (Tablo 3).

Tablo 4'te yer alan korelasyon analizi sonuçları, VA ile VKİ, VYY ve SFK arasında pozitif; VKİ ile VYY ve SFK arasında pozitif; sağ ve sol EKK ile VKİ arasında negatif; EKK ile SK ve E arasında pozitif; SK ile BK arasında pozitif; E ile KG arasında pozitif; VYY ile SFK arasında pozitif; KSE ile ÖS arasında negatif bir ilişki olduğunu işaret etmektedir. Yani vücut ağırlığ 1 ile vücut yağ yüzdesi ve vücut kitle indeksi karşılıklı ilişki içindedir. Bir başka deyişle vücut yağ yüzdesinde meydana gelen değişim SFK'yi arttırmakta veya azaltmaktadır. Diğer taraftan BKO ve VO2maks ile diğer değişkenler arasında herhangi bir ilişkiye rastlanmamıştır. VA aynı zamanda SFK ile de etkileşim içindedir, yani, vücut ağırlığının artması veya azalması bedenle ilgili duyulan fizik kaygıda farklılık yaratmaktadır. Benzer ilişki VYY ile SFK arasında da tespit edilmiştir. Vücut yağ yüzdesindeki farklılaşma sosyal ortamda bedenle ilgili duyulan kaygı düzeyinin belirleyicisi durumundadir.

Tablo 2. Eşli Grupların İlk ve Son Ölçüm Ortalamalarının Karşılaştırılması

\begin{tabular}{|c|c|c|c|c|c|c|c|c|}
\hline Değişken & Gruplar & Ölçüm & $n$ & $\overline{\mathrm{X}}$ & $s S$ & sho & $t$ & $p$ \\
\hline \multirow{2}{*}{ VA } & EG & İlk-Son & 37 & 4,48919 & 1,88057 & ,30916 & 14,520 &, $000^{*}$ \\
\hline & KG & İlk-Son & 37 &,- 05135 &, 21810 & ,03586 & $-1,432$ &, 161 \\
\hline \multirow{2}{*}{$\mathrm{BKO}$} & EG & İlk-Son & 37 &, 04242 &, 02533 &, 00416 & 10,187 &, $000^{*}$ \\
\hline & KG & İlk-Son & 37 & 00052 & 00473 & 00078 &, 671 &, 507 \\
\hline \multirow{2}{*}{ VKİ } & EG & İlk-Son & 37 & 1,71181 & ,71814 & ,11806 & 14,499 &, $000^{*}$ \\
\hline & KG & İlk-Son & 37 &,- 00854 &, 02946 & ,00484 & $-1,764$ &, 086 \\
\hline \multirow[b]{2}{*}{ EKK Sağ } & EG & İlk-Son & 37 & 00270 & 02874 & 00472 &, 572 & 571 \\
\hline & KG & İlk-Son & 37 &,- 00676 & , 02096 & 00345 & $-1,961$ & , 058 \\
\hline \multirow{2}{*}{ EKK Sol } & EG & İlk-Son & 37 &,- 12973 & 63284 &, 10404 & $-1,247$ & 220 \\
\hline & KG & İlk-Son & 37 &,- 12973 & 63284 &, 10404 & $-1,247$ & 220 \\
\hline \multirow{2}{*}{ SK } & EG & İlk-Son & 37 & $-17,17568$ & 7,95754 & 1,30821 & $-13,129$ &, $000^{*}$ \\
\hline & KG & İlk-Son & 37 &, 01486 &, 09344 & 01536 &, 968 &, 340 \\
\hline \multirow{2}{*}{ BK } & EG & İlk-Son & 37 & $-15,04054$ & 8,49622 & 1,39677 & $-10,768$ &, $000^{*}$ \\
\hline & KG & İlk-Son & 37 &,- 00811 &, 23378 & 03843 &,- 211 &, 834 \\
\hline \multirow{2}{*}{$\mathrm{E}$} & EG & İlk-Son & 37 & $-4,06162$ &, 75183 &, 12360 & $-32,861$ &, $000^{*}$ \\
\hline & KG & İlk-Son & 37 &, 01162 & 04106 & 00675 & 1,722 &, 094 \\
\hline \multirow{2}{*}{ VYY } & EG & İlk-Son & 37 & 3,39953 & 1,90995 & ,31399 & 10,827 &, $000^{*}$ \\
\hline & KG & İlk-Son & 37 &,- 02190 &, 16815 & , 02764 &,- 792 &, 433 \\
\hline \multirow[b]{2}{*}{$\mathrm{VO}_{2 \max }$} & EG & İlk-Son & 37 & $-4,40000$ & ,95924 & 15770 & $-27,901$ & ,000* \\
\hline & KG & İlk-Son & 37 &,- 26649 & ,78669 & ,12933 & $-2,061$ &, 047 \\
\hline \multirow{2}{*}{ SFK } & EG & İlk-Son & 37 & 4,86486 & 1,73465 & ,28517 & 17,059 &, $000^{*}$ \\
\hline & KG & İlk-Son & 37 &,- 10811 &, 31480 &, 05175 & $-2,089$ &, 044 \\
\hline \multirow{2}{*}{ KSE } & EG & İlk-Son & 37 & 2,37838 & 2,05955 & 33859 & 7,024 &, $000^{*}$ \\
\hline & KG & İlk-Son & 37 & , 18919 & ,39706 & ,06528 & 2,898 & ,006 \\
\hline \multirow{2}{*}{ ÖS } & EG & İlk-Son & 37 & 48649 &, 55885 & 09187 & 5,295 &, $000^{*}$ \\
\hline & KG & İlk-Son & 37 &,- 08108 &, 36350 & 05976 & $-1,357$ &, 183 \\
\hline \multirow{2}{*}{ GFY } & EG & İlk-Son & 37 & $-6,13514$ & 3,18121 & ,52299 & $-11,731$ &, $000^{*}$ \\
\hline & KG & İlk-Son & 37 &, 10811 & 31480 & 05175 & 2,089 &, 044 \\
\hline \multirow{2}{*}{ KEG } & EG & İlk-Son & 37 & $-4,37838$ & 3,89695 & 64065 & $-6,834$ & , $000^{*}$ \\
\hline & KG & İlk-Son & 37 &, 16216 & 37368 & 06143 & 2,640 &, 012 \\
\hline
\end{tabular}


Tablo 3. Bağımsız Grupların İlk ve Son Ölçüm Ortalamalarının Karşılaştırılması

\begin{tabular}{|c|c|c|c|c|c|c|c|}
\hline Değişken-Ölçüm & Gruplar & $n$ & $\overline{\mathrm{X}}$ & $s s$ & sho & $t$ & $p$ \\
\hline \multirow{2}{*}{ VA- İlk } & KG & 37 & 69,5946 & 3,65794 & ,60136 & \multirow{2}{*}{,- 953} & \multirow{2}{*}{,344 } \\
\hline & EG & 37 & 70,4405 & 3,96852 & ,65242 & & \\
\hline \multirow{2}{*}{ VA-Son } & KG & 37 & 69,6108 & 3,65626 & ,60108 & \multirow{2}{*}{3,896} & \multirow{2}{*}{, $000^{*}$} \\
\hline & EG & 37 & 65,9514 & 4,39113 & ,72190 & & \\
\hline \multirow{2}{*}{ BKO- İlk } & KG & 37 &, 9735 &, 02675 &, 00440 & \multirow{2}{*}{,- 419} & \multirow{2}{*}{,676 } \\
\hline & EG & 37 & 9765 &, 03335 &, 00548 & & \\
\hline \multirow{2}{*}{ BKO-Son } & KG & 37 & ,9730 & ,02708 & ,00445 & \multirow{2}{*}{4,964} & \multirow{2}{*}{, $000 *$} \\
\hline & EG & 37 &, 9341 &, 03930 & 00646 & & \\
\hline \multirow{2}{*}{ VKİ-İlk } & KG & 37 & 26,3678 & 2,00893 & ,33027 & \multirow{2}{*}{$-1,038$} & \multirow{2}{*}{,303 } \\
\hline & EG & 37 & 26,8519 & 2,00191 & ,32911 & & \\
\hline & $\mathrm{KG}$ & 37 & 26,6307 & 2,04699 & ,33652 & & \\
\hline VKI-Son & EG & 37 & 25,1401 & 2,07011 & ,34032 & 3,114 &, $003 *$ \\
\hline & KG & 37 & 22,5730 & 5,13158 & ,84363 & & \\
\hline EKK Sağ-Ilk & EG & 37 & 21,9243 & 5,16416 & ,84898 & ,542 & ,590 \\
\hline & KG & 37 & 22,5797 & 5,12797 & ,84303 & & \\
\hline EKK Sağ-Son & EG & 37 & 21,9216 & 5,17269 & ,85039 & ,550 & ,584 \\
\hline & KG & 37 & 22,0405 & 5,44964 & ,89592 & & \\
\hline EKK Sol-Ilk & EG & 37 & 21,3946 & 5,52323 & 90801 &, 506 & ,614 \\
\hline & KG & 37 & 22,1703 & 5,40246 & ,88816 & & \\
\hline EKK Sol-Son & EG & 37 & 21,5243 & 5,47846 & ,90065 & (511 & ,611 \\
\hline & $\mathrm{KG}$ & 37 & 64,9432 & 18,21157 & 2,99396 & & \\
\hline SK-Ilk & EG & 37 & 64,2973 & 18,18976 & 2,99038 & , 153 & ,879 \\
\hline & KG & 37 & 64,9284 & 18,19316 & 2,99094 & & \\
\hline SK-Son & EG & 37 & 81,4730 & 16,03033 & 2,63537 & $-4,150$ &, $000^{*}$ \\
\hline & KG & 37 & 52,9162 & 16,20525 & 2,66413 & & \\
\hline BK-Ilk & EG & 37 & 52,2703 & 16,22652 & 2,66762 &, 171 & ,864 \\
\hline & KG & 37 & 52,9243 & 16,15020 & 2,65508 & & \\
\hline BK-Son & EG & 37 & 66,7838 & 14,69010 & 2,41504 & $-3,862$ &, $000 *$ \\
\hline F İll & KG & 37 & 8,8684 & 3,56380 &, 58588 & & \\
\hline E-Ilk & EG & 37 & 8,9143 & 3,55982 & ,58523 &,- 055 & ,956 \\
\hline & KG & 37 & 8,8568 & 3,56737 & ,58647 & & \\
\hline E-Son & EG & 37 & 12,9759 & 3,63821 & ,59812 & $-4,917$ &, $000^{*}$ \\
\hline & KG & 37 & 26,1339 & 5,42892 & ,89251 & & \\
\hline VYY-Ilk & EG & 37 & 25,7041 & 5,06112 & 83204 & ,352 &, 726 \\
\hline & KG & 37 & 26,1558 & 5,44711 & 89550 & & \\
\hline VYY-Son & EG & 37 & 22,3046 & 4,98201 & ,81904 & 3,173 &, $002^{*}$ \\
\hline & KG & 37 & 38,7751 & 5,98550 & ,98401 & & \\
\hline $\mathrm{VO}_{2 \max -\text { Ilk }}$ & EG & 37 & 38,8211 & 5,99811 & ,98608 &,- 033 & ,974 \\
\hline & KG & 37 & 39,0416 & 5,86430 & ,96409 & & \\
\hline $\mathrm{VO}_{2 \max }-\mathrm{Son}$ & EG & 37 & 43,2211 & 5,88842 & ,96805 & $-3,059$ &, $003 *$ \\
\hline & KG & 37 & 35,5676 & 8,39822 & 1,38066 & & \\
\hline SFK-Ilk & EG & 37 & 34,7838 & 8,35043 & 1,37280 & ,403 & ,688 \\
\hline & KG & 37 & 35,6757 & 8,41313 & 1,38311 & & \\
\hline SFK-Son & EG & 37 & 29,9189 & 7,52912 & 1,23778 & 3,102 &, $003 *$ \\
\hline KSE İl & $\mathrm{KG}$ & 37 & 102,4054 & 36,18737 & 5,94917 & & \\
\hline KSE-IIK & EG & 37 & 101,6216 & 36,11659 & 5,93753 & , - 093 & ,926 \\
\hline & KG & 37 & 102,2162 & 36,14411 & 5,94205 & & \\
\hline KSE-Son & EG & 37 & 99,2432 & 35,06217 & 5,76419 & ,359 &, 721 \\
\hline & KG & 37 & 3,2973 &, 84541 & , 13898 & & \\
\hline ÖS-İlk & EG & 37 & 3,2162 & 1,00375 & , 16501 & ,376 & ,708 \\
\hline & KG & 37 & 3,3784 & ,98182 &, 16141 & & \\
\hline OS-Son & EG & 37 & 2,7297 &, 76915 &, 12645 & 3,163 &, $002 *$ \\
\hline & KG & 37 & 19,2432 & 4,96882 & ,81687 & & \\
\hline GFY-Ilk & EG & 37 & 20,0270 & 4,91306 & 80770 &,- 682 & 497 \\
\hline GFY_Son & KG & 37 & 19,1351 & 4,90556 & ,80647 & 7357 & $O O O *$ \\
\hline GFY-Son & EG & 37 & 26,1622 & 3,11371 & ,51189 & $-1,351$ &, $000^{*}$ \\
\hline & KG & 37 & 20,6216 & 4,73962 & ,77919 & & \\
\hline KEG-Ilk & EG & 37 & 21,4054 & 4,65749 & ,76569 &,- 717 & ,475 \\
\hline & KG & 37 & 20,4595 & 4,79927 & ,78900 & & \\
\hline KEG-Son & EG & 37 & 25,7838 & 3,48118 & 57230 & $-5,463$ &, $000 *$ \\
\hline
\end{tabular}


Tablo 4. Değişkenler Arası Korelasyon

\begin{tabular}{|c|c|c|c|c|c|c|c|c|c|c|c|c|c|c|c|}
\hline & $V A$ & $B K O$ & $V K \dot{I}$ & EKK Să & EKK Sol & $S K$ & $B K$ & E & $V Y Y$ & $V O_{2 \max }$ & $S F K$ & $K S E$ & $\ddot{O S}$ & $G F Y$ & $K E G$ \\
\hline$V A$ & 1 & & & & & & & & & & & & & & \\
\hline$B K O$ &,- 096 & 1 & & & & & & & & & & & & & \\
\hline$V K \dot{I}$ &, $786\left(^{*}\right)$ &,- 084 & 1 & & & & & & & & & & & & \\
\hline$\overline{E K K S a \breve{g}}$ &,- 145 & , 148 &,$- 416(*)$ & 1 & & & & & & & & & & & \\
\hline EKKSol &,- 214 & ,018 &,$- 407(*)$ &, $874(*)$ & 1 & & & & & & & & & & \\
\hline$S K$ &,- 148 & , 119 &,- 187 &, $535(*)$ &, $524(*)$ & 1 & & & & & & & & & \\
\hline$B K$ &,- 167 & ,029 &,- 200 &, $412(*)$ & 294 & ,436(*) & 1 & & & & & & & & \\
\hline$E$ &,- 073 & ,059 &,- 176 &, $397(*)$ & ,487(*) & 249 &,- 108 & 1 & & & & & & & \\
\hline$V Y Y$ &, $418(*)$ & ,015 &, $535(*)$ &,- 124 &,- 210 &,- 322 &,- 107 &,- 149 & 1 & & & & & & \\
\hline$V O_{2 \max }$ & ,048 & ,051 &, 040 &,- 129 &,- 199 & ,045 & ,001 &,- 161 & ,208 & 1 & & & & & \\
\hline$S F K$ &, $603\left(^{*}\right)$ &,- 047 &, $703(*)$ &,- 269 &,- 259 &,- 097 &,- 089 &,- 134 &, $466(*)$ & ,227 & 1 & & & & \\
\hline$K S E$ &, 118 & ,079 &,- 024 &, 232 &, 182 &,- 101 &,- 211 & 320 & ,280 & 014 &,- 033 & 1 & & & \\
\hline$\ddot{O S}$ &,- 105 & ,219 &,- 171 & ,228 & , 126 & ,216 & ,307 &,- 122 &,- 319 &, 131 &,- 033 &,$- 466(*)$ & 1 & & \\
\hline$G F Y$ &,- 070 &,- 223 & 080 &, 015 & ,046 &,- 070 &,- 129 &, 101 & ,295 & 091 & ,279 &, 128 &,$- 376(*)$ & 1 & \\
\hline$K E G$ &,- 251 & ,243 &,- 295 & ,239 & , 198 & ,277 & ,029 &, $489(*)$ &,- 273 &,- 264 &,- 224 & ,012 & ,206 &,- 122 & 1 \\
\hline
\end{tabular}

\section{Sonuç ve Değerlendirme}

Düzenli ve uzun süreli tae-bo egzersiz programına katılımın sedanter aşırı kilolu (bayan) üniversite öğrencilerinin fiziksel, motorik ve psiko-sosyal parametrelerine etkisini belirlemek amacıyla tasarlanan çalışmanın bu bölümünde katılımcılardan elde edilen verilere uygulanan istatistiksel analizlerle ulaşılan sonuçlar alanyazına göre tartışılmış ve bazı önerilerde bulunulmuştur.

Mevcut alanyazında aerobik egzersizin fiziksel, fizyolojik ve motorik özelliklere olan etkisini konu edinen çalışmalar proje çalışmamızdan elde edilen sonuçları desteklemektedir. Çolakoğlu ve Şenel (2003), sekiz haftalık aerobik (koş-yürü) egzersiz, Karacan vd. (2004), on iki haftalık aerobik egzersiz, Patlar vd. (2005), sekiz haftalık aerobik egzersiz, Erbaş (2007) altı aylık aerobik egzersiz, İri vd. (2010), sekiz haftalık yürüyüş egzersiz, Stasiulis vd., (2010) sekiz haftalık aerobik bisiklet egzersiz uygulaması akabinde obez ve sedanter kadınların VA, VYY ve VKİ puanlarında anlamlı azalmayı raporlamışlardır. Aşırı kilolu veya obez 173 sedanter kadına uygulanan 12 haftalık aerobik egzersiz programı VO2maks ve VA ölçümlerinde anlamlı fark sağlamıştır (Campbell vd., 2010). Sedanter 20 kadınla 8 hafta sürdürülen aerobik-koş-yürü egzersizleri sonrasında VA, VKİ, VYY ve BKO değişkenlerinde anlamlı farklılık bulunmuştur (Kızılay, 2012). Sekiz haftalık step-aerobik egzersiz programı sonucunda sedanter obez 15 gönüllü ve sağlıklı kadının VA, VKİ, E, Vo2maks, SK, BK, sağ ve sol EKK ve VYY puanlarının anlamlı olarak değiştiğini belirlenmiştir (Kurt, 2007). Marandi vd. (2013), obez 45 kadında hem düşük hem de orta-yüksek yoğunluklu aerobik egzersiz sonrasında BKO değerinde anlamlı iyileşme gözlemişlerdir. Altunsoy (2014), sekiz haftallk aerobik egzersizin vücut yağ yüzdeleri \% 25-35 olan, 18-25 yaş arası, 22 sedanter kadın gönüllü deneğin $\mathrm{BKO}$ değerlerinde anlamlı azalma sağladığı sonucuna varmıştır.

Çalışmamızda kullanılan tae-bo egzersizinin etkilerini doğrudan ele alan mevcut sınırlı sayıdaki araştırmalardan birinde Boeva vd. (2003), tae-bo egzersizine katılımın fiziksel becerilerde, sağlık durumunda ve motivasyonda olumlu artış sağladığını belirtirken, başka bir araştırmada bu faydalarına ilaveten VKİ ve deri altı yağını azalttığı da raporlanmıştır (Petkovic vd., 2007). Mikic vd. (2009), taebo egzersizinin 6 ay sonunda üniversite öğrencilerinin fiziksel işlev becerilerini olumlu olarak etkilediğini belirlemişlerdir. Milenkovic ve Veselinovic (2010), üç aylık tae-bo egzersiz programına aldıkları 18-25 yaş arası 30 kadını düzenli egzersiz yapmayan kontrol grubu ile lokomotor testler açısından karşılaştırmış ve egzersiz grubunun motorik özelliklerinin ve koordinasyonun anlamlı olarak farklılaştığını ortaya koymuşlardır. Oh vd. (2010) yaşam biçimi değişimi bağlamında kadınlarda 6 ay boyunca uyguladıkları tae-bo içerikli egzersiz programı sonucunda kontrol grubuna kıyasla; VA, BKO, fiziksel işlev genel sağlık ve mental sağlık açısından anlamlı gelişimler tespit etmişlerdir. Tae-bo egzersizinin hız, hareket, kassal kuvvet, dayanıklılık ve çabukluk gibi kinestetik algılara olan etkisi 20 yaş civarı katılımcılarda test edilmiş, son ölçümler egzersiz grubu lehine anlamlı fark yaratmıştır (El Roby, 2010). Mustedanagic vd. (2014), tae-bo egzersizinin belli uygunluk becerilerine etkilerini ortaya çıkarmayı amaçladıkları çalışmada, yaşları 22-27 arasında değişen 60 genç kadınla çalışmışlardır. Haftada 4 gün ve 8 hafta süren tae-bo programının özellikle kassal dayanıklılık kol ve bacak extansörleri, torso fleksörleri, kalp-solunum dayanıklılığı ve esnekliğe olumlu etki ettiği sonucuna varmışlardır. Nikic ve Milenkovic (2014), tae-bo egzersizi uyguladıkları kadınlarla yürüttükleri bir diğer çalışmada kuvvet ve denge açısından egzersiz grubu lehine anlamlı sonuçlar elde etmişlerdir. Tekin vd. (2015), düzenli tae-bo egzersiz programına katılımın üniversiteli obez kız öğrencilerin fiziksel, motorik ve psikososyal parametrelerine etkisini belirlemek amacıyla 40 obez üniversite öğrencisi ile 3 ay çalışmışlar; programın katılımcıların fiziksel, motorik ve psikososyal değişkenlerini olumlu etkilediği sonucuna varmışlardır. Djordjevic vd. (2015) kadınlara uyguladıkları 12 haftalık tae-bo ve pilates programlarının etkilerini karşılaştırmış, sadece tae-bo grubunda vücut kompozisyonunun olumlu değişimini gözlemlemişlerdir. Mevcut alanyazında ulaşılabilen ve içinde bulunduğumuz yıla ait en güncel araştırmada, Tae-bo, kardiyo-metabolik hastalık ve kilo riskini azaltmada bir 
müdahale aracı olarak ele alınmıştır. Bu amaçla sedanter yaşam süren 25 yaş ortalamasına sahip 60 obez/aşırı kilolu (VKİ=25-39.9 kg/m2) kadın üniversite öğrencisi ilk 5 hafta orta sonraki 5 hafta yüksek şiddette toplam 10 hafta tae-bo egzersiz programına dâhil edilmiștir. Egzersiz sonucunda metabolik sendrom yüzdesi, VA, VKİ, ve BKO, dinlenik kalp atım sayısı, sistolik ve diastolik kan basınçları anlamlı şekilde azalmıştır (Mathunjwa vd., 2016).

Mevcut alanyazında yer alan ve çalışmamızda ele alınan değişkenler arasındaki ilişkiyi gözlemleyen araştırmalar proje çalışmamızdan elde edilen bazı sonuçları desteklemektedir.

Kaygı bozuklukları önemli bir halk sağlığı sorunudur. Klinik olmayan popülasyon çalışmalarından elde edilen kanıtlar, egzersizin kayg1 üzerindeki olumlu etkilerinden söz etmektedir (DeBoer vd., 2012). Mülazimoğlu-Ballı vd., (2010) sporcular ve egzersiz yapanların sedanterlere göre daha düşük SFK düzeylerine sahip olduklarını bildirmişlerdir. Koyuncu vd. (2010), VYY, SFK, beden imgesi (Bİ) ve ÖS arasındaki ilişkiyi egzersiz yapan ve sedanter kadınlarda araştırmışlar; SFK, beden imgesi ve ÖS arasında anlamlı ilişkiler ve her iki grup arasında bu değişkenlerde anlamlı farklar bulmuşlardır. Egzersiz davranışı SFK, Bİ ve ÖS üzerinde etkilidir. Fiziksel benlik algısı, SFK ve başarı motivasyonu arasındaki ilişki spor merkezlerine düzenli devam edenlerde etmeyenlere göre oldukça güçlüdür (Hagger vd., 2011). Streeter vd. (2012), kadınlarda VKİ ve VYY 'nin birbirleriyle yüksek düzeyde pozitif ilişkili ancak beden imgesi ile negatif ilişkili olduğunu belirtmişlerdir. Ali vd. (2010), algılanan kilo durumu ile mental sağlık, depresif semptomlar ve özsaygı arasında güçlü ve anlamlı bir ilişkiden söz etmişlerdir. Kadınların normal ve veya daha az kilolu olduklarında beden doyumlarının daha yüksek olduğu kilo arttıkça bu doyumun azaldığı, aşırı kilolu ve obez olanlarda beden memnuniyeti yanında özsaygının da azaldığı raporlanmıştır. Dolayısıyla beden kitlesi, özsaygı ve beden doyumu arasında kuvvetli bir ilişki vardır (Makinen vd., 2012). Bir diğer araştırmada beden imgesi ve VA sınıflaması arasında açık ilişki bulunmuştur. Obez gençler aşırı kilolulara, aşırı kilolular normal kilolu olanlara göre daha yüksek beden memnuniyetsizliği bildirmişlerdir. Obez gençler, aşırı kilolu ve normal kilolu olanlara göre daha yüksek depresyon ve olumsuz özsaygı puanlarına sahiptirler (Goldfield vd., 2010). Sağlık davranışları, VKİ ve özsaygı arasındaki ilişkiyi 2000 genç üzerinde inceleyen bir araştırmada sağlık ve fiziksel egzersiz davranışları ile özsaygı arasında pozitif bir ilişki gözlenmiştir. Özsaygı, VKİ artışından olumsuz şekilde etkilenmektedir (Kristjansson vd., 2010). Bir başka araştırmada, yaşları 38 civarı, $\mathrm{VKI}=30.23 .7 \mathrm{~kg} / \mathrm{m} 2$ olan 142 aşırı kilolu veya obez kadında VA, beden imgesi ve psikolojik iyilik ilişkisini 4 aylık egzersiz temelli davranışsal tedavi programı ve 12 aylık izleme sonrası test etmişler 4 ay sonucu VA'da meydana gelen azalmanın psikososyal değişkenlerde olumlu değişime yol açtığını belirlemişılerdir. Dolayısıyla obezite tedavisi programı sonrası VA değişimi, bilişsel ve duygulanım ilişkili süreçleri de etkilenmiştir (Palmeira vd., 2010).

$\mathrm{Bu}$ çalışmadan elde edilen sonuçlar aşağıdaki şekilde özetlenebilir: (i) Tae-bo egzersizi EG açısından VA, BKO, VKİ, SK, $\mathrm{BK}, \mathrm{E}, \mathrm{VYY}, \mathrm{VO}_{2 \max }$ değerlerinde olumlu ve anlamlı fark yaratmıştır.

(ii) Tae-bo egzersizi EG açısından SFK, KSE, ÖS, GFY ve $\mathrm{KG}$ değerlerinde olumlu ve anlamlı fark yaratmıştır.

(iii) Tae-bo egzersizine katılmayan $\mathrm{KG}$ grubu VO2maks, SFK, KSE, GFY ve KG değerleri grubun aleyhine başlangıç düzeylerine göre anlamlı şekilde azalmıştır.

(iv) $\mathrm{EG}$ ve $\mathrm{KG}$ grubunda başlangıç (ilk ölçüm) aşamasında fark yoktur.

(v) Tae-bo egzersizi EG ve $\mathrm{KG}$ grubu arasında son ölçümlerde; VA, BKO, VKİ, SK, BK, E, VYY, $\mathrm{VO}_{2 \max }$, SFK, ÖS, GFY ve KG puan ortalamalarında EG katılımcıları lehine olumlu ve anlamlı bir fark yaratmıştır.

(vi) Tae-bo egzersizi KSE ve EKK değerlerine etki yapmamıştır.

(vii) VA ile VKİ, VYY ve SFK arasında pozitif bir ilişki vardir.

(viii) VKİ ile VYY ve SFK arasında pozitif bir ilişki vardır.

(ix) Sağ ve sol EKK ile VKİ arasında negatif bir ilişki vardir.

(x) EKK ile SK ve E arasında pozitif bir ilişki vardır.

(xi) SK ile BK arasında pozitif bir ilişki vardır.

(xii) E ile $\mathrm{KG}$ arasında pozitif bir ilişki vardır.

(xiii) VYY ile SFK arasında pozitif bir ilişki vardır.

(xiv) KSE ile ÖS arasında negatif bir ilişki vardır.

(xv) Proje çalışmamızın son aşamasında şu öneriler verilebilir:

(xvi) Katılımcıların çoğunun ülkemizin Güney ve Doğu Anadolu bölgesinden olması iklim, kültür ve sosyal yaşam farkı nedeniyle fiziksel ve psiko-sosyal değişkenlerden elde edilen puanları etkilemiş olabilir. $\mathrm{Bu}$ nedenle benzer bir çalışmanın belirtilen değişkenler açısından farklı üniversitelerin öğrencileriyle tasarlanması önerilebilir.

(xvii) Katılımcı sayısı arttırılarak çalışma yeniden tasarlanabilir.

(xviii) Cinsiyetlere göre karşılaştırma yapılabilmesi için erkek öğrencilerin çalışmaya katılması önerilebilir.

(xix) Tae-bo ve başka bir aerobik egzersiz çalışmada birlikte uygulanarak etki açısından karşılaştırma yapılması önerilebilir.

$\mathrm{Bu}$ araştırmanın sonuçları kullanılan ölçüm araçları ve katılımcılardan elde edilen verilerle sinırlıdır. Genelleme yapilamaz.

\section{Kaynakça}

Ainsworth, B.E., Haskell, W.L., Leon, A.S., Jacobs Jr, D.R., Montoye, H.J., Sallis, J.F., \& Paffenbarger Jr, R.S. (1993). Compendium of physical activities: classification of energy costs of human physical activities. Medicine and Science in Sports and Exercise, 25(1), 71-80.

Akdur, H. (2011). The effect of walking and step aerobic exercise on physical fitness parameters in obese women. İstanbul Tıp Fakültesi Dergisi, 70(3), 64-69.

Ali, M.M., Fang, H., \& Rizzo, J.A. (2010). Body weight, self-perception and mental health outcomes among adolescents. The Journal of Mental Health Policy and Economics, 13(2), 53-63. 
Altunsoy, K. (2014). Aerobik Egzersiz ve Kombine Egzersiz Uygulamalarının Vücut Kompozisyonu ve Dinlenim Metabolik Ho Üzerine Olan Etkilerinin İncelenmesi. Yüksek Lisans Tezi. Bolu: Abant İzzet Baysal Üniversitesi.

Asmundson, G.J., Fetzner, M.G., DeBoer, L.B., Powers, M.B., Otto, M.W., \& Smits, J.A. (2013). Let's get physical: a contemporary review of the anxiolytic effects of exercise for anxiety and its disorders. Depression and Anxiety, 30(4), 362-373.

Aşçı, F.H. (2000). The Reliabilty and Validity of PSDQ for Turkish Population. Congress Proceedings of $\mathrm{V}^{\text {th }}$ Sport Sciences Congress, 3-5 November, Ankara: Hacettepe University, 122-123.

Aydın, İ., \& Yiğit F. (2003). Şişman Öğrencilerin Anksiyete Durumunun İncelenmesi, Hemşirelik Forumu Dergisi, 6(4), 48-52.

Baltac1, G. (2008). Fiziksel Aktivite Bilgi Serisi: Koordinatör: Prof. Dr. Gül Baltacı, Editörler: Yrd. Doç. Dr. Hasan Irmak, Uzm. Gıda Müh. Cengiz Kesici, Gıda. Müh. Ertuğrul Çelikcan, Dr. Dyt. Biriz Çakır: Obezite ve Egzersiz, Klasmat Matbaacılık, Ankara, 80-88.

Boeva, B., Angelova, T., Ivanova, V., \& Serafimova, M. (2003). Physical education and sport for ecology directed development of man. Trakia Journal of Science, 1(1), 4243.

Bredin, S.S., Warburton, D. E., \& Lang, D.J. (2013). The health benefits and challenges of exercise training in persons living with schizophrenia: a pilot study. Brain Sciences, 3(2), 821-848.

Britz, B., Siegfried, W., \& Ziegler, A. (2000). Rates of Psychiatric Disorders in a Clinical Study Group of Adolescents with Extreme Obesity and in Obese Adolescents Ascertained via a Population Based Study. International Journal of Obesity Related Metabolic Disorders, 24(12), 1707-1714.

Buffart, L. M., Galvão, D.A., Chinapaw, M.J., Brug, J., Taaffe, D.R., Spry, N., \& Newton, R.U. (2014). Mediators of the resistance and aerobic exercise intervention effect on physical and general health in men undergoing androgen deprivation therapy for prostate cancer. Cancer, 120(2), 294-301.

Campbell, P.T., Gross, M.D., Potter, J.D., Schmitz, K.H., Duggan, C., McTiernan, A., \& Ulrich, C.M. (2010). Effect of exercise on oxidative stress: a 12-month randomized, controlled trial. Medicine and Science in Sports and Exercise, 42(8), 1448.

Cooper, K.H. (2013). Aerobics Program For Total WellBeing: Exercise, Diet, And Emotional Balance. Random House LLC.

Çolakoğlu, F., \& Şenel, Ö. (2003). Sekiz haftalık aerobik egzersiz programının sedanter orta yaşlı bayanların vücut kompozisyonu ve kan lipitleri üzerindeki etkileri. Spormetre, 13(1), 57-61.

Çuhadaroğlu, F. (1986). Adolesanlarda Benlik Saygısı. Uzmanlık Tezi. Ankara: Hacettepe Üniversitesi.
DeBoer, L.B., Powers, M.B., Utschig, A.C., Otto, M.W., \& Smits, J.A. (2012). Exploring exercise as an avenue for the treatment of anxiety disorders. Expert review of Neurotherapeutics, 12(8), 1011-1022.

Dikici, A. (2013). Obez bireylerde düşük ve yüksek yoğunluklu aerobik egzersiz programının etkilerin karşılaştırılması. Uzmanlı Tezi. Afyon: Afyon Kocatepe Üniversitesi.

Djordjevic, D., Tosic, J.S., Stefanovic, D., Barudzic, N., Vuletic, M., Zivkovic, V., \& Jakovljevic, V. (2015). The Effects Of Two Fitness Programs With Different Metabolic Demands On Oxidative Stress In The Blood Of Young Females. Serbian Journal of Experimental and Clinical Research, 16(2), 101-107.

El Roby, A.A.A. (2010). The effect of a tae bo exercise program on physical fitness and some kinesthetic perceptions for university level basketball players in Egypt. World Journal of Sport Sciences, 3(2), 107-112.

Erbaş, Ü. (2007). Orta Yaş Obez Bayanlara Yönelik Kalistenik Egzersizlerin Fiziksel ve Fizyolojik Etkileri. Yüksek Lisans Tezi. Ankara: Gazi Üniversitesi.

Eren, İ., \& Erdi, Ö. (2003). Obez Hastalarda Psikiyatrik Bozuklukların Sıklığı. Klinik Psikiyatri, 6(3), 152-157

Gary, R.A. (2013). Aerobic exercise reduces depressive symptoms in patients with chronic heart failure. Evidence Based Mental Health, 16(2), 42-42.

Gerber, M., Brand, S., Elliot, C., Holsboer-Trachsler, E., Pühse, U., \& Beck, J. (2013). Aerobic exercise training and burnout: a pilot study with male participants suffering from burnout. BMC Research Notes, 6(1), 78.

Goldfield, G.S., Moore, C., Henderson, K., Buchholz, A., Obeid, N., \& Flament, M.F. (2010). Body dissatisfaction, dietary restraint, depression, and weight status in adolescents. Journal of School Health, 80(4), 186-192.

Gordon, C.D., Wilks, R., \& McCaw-Binns, A. (2013). Effect of Aerobic Exercise (Walking) Training on Functional Status and Health-related Quality of Life in Chronic Stroke Survivors A Randomized Controlled Trial. Stroke, 44(4), 1179-1181.

Greer, N. (2016). Tae-bo: Fitness Craze or Effective Workout?. Tennessee: Vanderbilt University. (Erişim: 10.10.2017), www.vanderbilt.edu/AnS/psychology/ health_psychology/TAEBO.htm

Hagger, M.S., Hein, V., \& Chatzisarantis, N.L. (2011). Achievement Goals, Physical Self _Concept, and Social Physique Anxiety in a Physical Activity Context1. Journal of Applied Social Psychology, 41(6), 1299-1339.

Halder, K., Chatterjee, A., Pal, R., Tomer, O.S., \& Saha, M. (2015). Age related differences of selected Hatha yoga practices on anthropometric characteristics, muscular strength and flexibility of healthy individuals. International Journal of Yoga, 8(1), 37.

Hart, E.A., Leary, M.R., \& Rejeski, W.J. (1989). The Measurement of Social Physique Anxiety. Journal of Sport \& Exercise Psychology, 11(1), 94-104. 
Hižnayová, K. (2013). Exercise intensity during Zumba fitness and Tae-bo aerobics. Journal of Human Sport and Exercise, 8(2), 228-241.

Ho, C.W., Chan, S.C., Wong, J. S., Cheung, W.T., Chung, D.W., \& Lau, T.F. (2014). Effect of Aerobic Exercise Training on Chinese Population with Mild to Moderate Depression in Hong Kong. Rehabilitation Research and Practice, 1-8.

İri, R., Ersoy, A., \& İri, R. (2010). Yürüyüş egzersizinin bayanların aerobik kapasitelerine ve bazı kan değerlerine etkisi. Uluslararası İnsan Bilimleri Dergisi, 7(2), 504 515 .

Karaca, A., Ergen, E., \& Koruç, Z. (2000). Fiziksel aktivite değerlendirme anketi (FADA) güvenilirlik ve geçerlilik çalışması. Spor Bilimleri Dergisi, 11(1-2-3-4), 17-28.

Karacan, S., Çolakoğlu, F.F., \& Erol, A.E. (2004). Obez Orta Yaş Bayanlar ile Menopoz Dönemindeki Bayanlarda Aerobik Egzersizin Bazı Fiziksel Uygunluk Değerlerine Etkisi. Erciyes Üniversitesi Săglı Bilimleri Dergisi, 13(1), 35-42.

Kizilay, F. (2012). Aerobik Egzersizin Sedanter Bayanlarda Vücut Kompozisyonu, Bazal Metabolizma Hizl, Total Oksidan ve Antioksidan Kapasite Üzerine Etkisinin Incelenmesi. Yüksek Lisans Tezi. Malatya: İnönü Üniversitesi.

Koyuncu, M., Tok, S., Canpolat, A. M., \& Catikkas, F. (2010). Body image satisfaction and dissatisfaction, social physique anxiety, self-esteem, and body fat ratio in female exercisers and nonexercisers. Social Behavior and Personality: an international journal, 38(4), 561570.

Köksal, F., Koruç, Z., \& Kocaekşi, S. (2006). 8 Haftalık Step-aerobik Dansına Katılımın Kadınlarda Fiziksel Benlik Alglsl Üzerine Etkisi. 9. Uluslararası Spor Bilimleri Kongresi, Muğla, 1033-1035.

Kristjansson, A. L., Sigfusdottir, I. D., \& Allegrante, J. P. (2010). Health behavior and academic achievement among adolescents: the relative contribution of dietary habits, physical activity, body mass index, and selfesteem. Health Education \& Behavior, 37(1), 51-64.

Kurt, S. (2007). Orta yaş sedanter bayanlarda 8 haftalık step aerobik egzersizinin bazl fiziksel uygunluk parametrelerine etkisi. Yüksek Lisans Tezi. Niğde: Niğde Üniversitesi.

Kurt, S., Hazar, S., İbiş, S., Albay, B., \& Kurt, Y. (2010). Evaluation of the effects of eightweek step-aerobic exercise program on some fitness parameters at middle aged sedentary women. International Journal of Human Sciences, 7(1), 665-674.

Kyle, U. G., Bosaeus, I., De Lorenzo, A. D., Deurenberg, P., Elia, M., Gomez, J. M., ... \& Scharfetter, H. (2004). Bioelectrical impedance analysis-part I: review of principles and methods. Clinical Nutrition, 23(5), 12261243.

Larsen, M. S., Vissing, K., Thams, L., Sieljacks, P., Dalgas, U., Nellemann, B., \& Christensen, B. (2014). Erythropoietin administration alone or in combination with endurance training affects neither skeletal muscle morphology nor angiogenesis in healthy young men. Experimental Physiology, 99(10), 1409-1420.

Lee, I.M., Paffenbarger, R.S., \& Hsieh C.C. (1992). Physical activity and risk of prostatic cancer among college alumni. American Journal of Epidemiology, 135(2), 169179.

Makinen, M., Puukko-Viertomies, L. R., Lindberg, N., Siimes, M. A., \& Aalberg, V. (2012). Body dissatisfaction and body mass in girls and boys transitioning from early to midadolescence: additional role of self-esteem and eating habits. BMC Psychiatry, 12(1), 1 .

Marandi, S. M., Abadi, N. G. B., Esfarjani, F., Mojtahedi, H., \& Ghasemi, G. (2013). Effects of intensity of aerobics on body composition and blood lipid profile in obese/overweight females. International Journal of Preventive Medicine, 4(Suppl 1), 118-125.

Marsh, H.W., Richards, G.E., Johnson, S., Roche, L., \& Tremayne, P. (1994). Physical Self Description Questionnaire: Psychometric Properties and a Multitraitmultimethod Analysis of Relations to Existing Instruments. Sport and Exercise Psychology, 16 (3), 270305.

Mathunjwa, M. L., Semple, S. J., \& du Preez, C. (2016). A 10 -week aerobic exercise program reduces cardiometabolic disease risk in overweight/obese female African university students. Ethnicity \& Disease, 23(2), 143-148.

McGuire, M.T, Wing, R.R, \& Klem, M.L. (1999). Behavioral strategies ofindividuals who have mainteined long-term weight losses. Obesity Research; 7(4), 334341.

Mikic, B., Dug, M., Tanovic, İ \& Mehinovic, J. (2009). Functional ability transformation processes of female students under influence of fitness program thai--_bo. Sport Science, 2 (2), 81-84.

Milenkovic, D., \& Veselinovic, N. (2010). Effect of experimental Tae Bo training model for coordination development of young women. Sport Science, 3(2), 5760 .

Moinuddin, I.K., Collins, E.G., Kramer, H.J., \& Leehey, D.J. (2012). Exercise in the management of obesity. Journal of Obesity and Weight Loss Therapy, 2(2), 2-12.

Mustedanagic, J., Jorgic, B., \& Cicovic, B. (2014). Effects of Tae Bo Aerobic Training Program on the Fitness Abilities of Young Women. Facta Universitatis, Series: Physical Education and Sport, 12(1), 41-49.

Mülazımoğlu-Ballı, Ö., \& Aşçı, F.H. (2006). Sosyal Fizik Kaygısı Envanterinin Geçerlik ve Güvenirlik Çalışması. Hacettepe Spor Bilimleri Dergisi, 17(1), 11-19.

Mülazimoğlu-Balli, Ö., Koca, C., \& Aşçi, F. (2010). An examination of social physique anxiety with regard to sex and level of sport involvement. Journal of Human Kinetics, 26(3), 115-122. 
Nikic, N., \& Milenkovic, D. (2014). Effects of Tae Bo recreational exercise on strength and balance in women. AGON International Journal of Sport Sciences, 4(2), 117-127.

Oh, E.G., Bang, S.Y., Hyun, S.S., Kim, S.H., Chu, S.H., Jeon, J.Y., \& Lee, J.E. (2010). Effects of a 6-month lifestyle modification intervention on the cardiometabolic risk factors and health-related qualities of life in women with metabolic syndrome. Metabolism, 59(7), 1035-1043.

Palmeira, A.L., Branco, T.L., Martins, S.C., Minderico, C.S., Silva, M.N., Vieira, P N., \& Teixeira, P. J. (2010). Change in body image and psychological well-being during behavioral obesity treatment: Associations with weight loss and maintenance. Body Image, 7(3), 187193.

Patlar, S., Çınar, V., Çakmakçı, O., \& Şahan, H. (2005). Sedanter Bayanlarda 8 Haftalık Düzenli Egzersiz ve Beslenme Programının Kilo Kaybına Etkisi. Atatürk Üniversitesi Beden Eğitimi ve Spor Bilimleri Dergisi, 7( 2), 72-77.

Petkovic, E., Veselinovic, N., \& Stojanovic-Tosic, J. (2007). Differences in circular dimensionality and subcutaneous fatty tissue at female subjects included at three months Tae bo exercise program. International Scientific Conference, Physical activity and health, Belgrade: Faculty of sport and physical education, 81-86.

Pi-Sunyer, X. (2009). The Medical Risks Of Obesity. Postgraduate Medicine, 121(6), 21-33.

Roppolo, M., Mulasso, A., Gollin, M., Bertolotto, A., \& Ciairano, S. (2013). The role of fatigue in the associations between exercise and psychological health in multiple sclerosis: Direct and indirect effects. Mental Health and Physical Activity, 6(2), 87-94.

Rosenberg, M. (1963). Parental interest and children's selfconceptions. Sociometry, 26(1), 35-49.

Sabiston, C.M., Pila, E., Pinsonnault-Bilodeau, G., \& Cox, A.E. (2014). Social physique anxiety experiences in physical activity: a comprehensive synthesis of research studies focused on measurement, theory, and predictors and outcomes. International Review of Sport and Exercise Psychology, 7(1), 158-183.

Salamuddin, N., Harun, M.T., \& Al-Rashed, S.A.A. (2014). The Effects of Selected Aerobic Exercise Modalities on Self Esteem among Female Students. Asian Social Science, 10(5), 141.

Saygın, Ö., Polat, Y., \& Karacabey, K. (2005). Çocuklarda Hareket Eğitiminin Fiziksel Uygunluk Özelliklerine Etkisi. Fırat Üniversitesi Sağlık Bilimleri Tıp Dergisi, 19(3), 205-212.

Sicilia, A., Saenz-Alvarez, P., Gonzalez-Cutre, D., \& Ferriz, R. (2014). Exercise Motivation and Social Physique Anxiety In Adolescents. Psychologica Belgica, 54(1), 111-129.

Siegel, J. M., Yancey, A. K., \& McCarthy, W. J. (2000). Overweight and depressive symptoms among AfricanAmerican women. Preventive Medicine, 31(3), 232-240.
Stasiulis, A., Mockiene, A., Vizbaraite, D., \& Mockus, P. (2010). Aerobic exercise-induced changes in body composition and blood lipids in young women. Medicina, 46(2), 129-134.

Streeter, V.M., Milhausen, R.R., \& Buchholz, A.C. (2012). Body image, body mass index, and body composition: In young adults. Canadian Journal of Dietetic Practice and Research, 73(2), 78-83.

Şahin, N., \& Durak, A. (1994). Kısa semptom envanteri: Türk gençleri için uyarlanması (Brief Symptom Inventory: Adaptation for the Turkish youth). Türk Psikoloji Dergisi, 9(31), 44-56.

Tekin, A., Tekin, G., Çalışır, M., \& Bayrakdaroğlu, S. (2015). Düzenli aerobik egzersiz programının üniversiteli obez kız öğrencilerin fiziksel, motorik ve psiko-sosyal parametrelerine etkisi. Spor ve Performans Araştırmaları Dergisi, 6(1), 19-29.

Thorogood, A., Mottillo, S., Shimony, A., Filion, K.B., Joseph, L., Genest, J., \& Eisenberg, M.J. (2011). Isolated aerobic exercise and weight loss: a systematic review and meta-analysis of randomized controlled trials. The American Journal of Medicine, 124(8), 747-755.

Torrance, G.M, Hooper, M.D., \& Reeder, B.A. (2002). Trends in overweight and obesity among adults in Canada (1970-1992): evidence from national surveys using measured height and weight. International Journal of Obesity Related Metabic Disordorders; 26(6), 797 804.

Tortop, Y, Ön, B.O., \& Öğün, E.S. (2010). Bayanlarda 12 Hafta Uygulanan Step-Aerobik Egzersiz Programının Bazı Fiziksel Uygunluk Parametreleri Üzerine Etkisi. Selçuk Üniversitesi Beden Eğitimi ve Spor Bilim Dergisi, 12(2), 91-97.

Vancampfort, D., De Hert, M., Knapen, J., Wampers, M., Demunter, H., Deckx, S., \& Probst, M. (2011). State anxiety, psychological stress and positive well-being responses to yoga and aerobic exercise in people with schizophrenia: a pilot study. Disability and Rehabilitation, 33(8), 684-689.

Vatansev, H., \& Çakmakçı, E. (2010). The effects of 8-week aerobic exercises on the blood lipid and body composition of the owerweight and obese females. Ovidius Univ Ann Phys Educ Sport Science \&Movement Health, 2, 814-820.

Yeltepe, H., \& Yargıç, İ.L. (2011). Egzersiz ve stres. Türkiye Klinikleri Psikiyatri Özel Dergisi, 4(3), 51-58.

Zorba, E., \& Ziyagil M.A. (1995). Vücut Kompozisyonu ve Ölçüm Metodları. Trabzon: Erek Ofset. 